ASTHMA

\title{
Written action plans for asthma: an evidence-based review of the key components
}

\author{
P G Gibson, H Powell
}

Thorax 2004;59:94-99. doi: 10.1136/thorax.2003.011858

See end of article for authors' affiliations

....................

Correspondence to: Dr P G Gibson, Hunter Medical Research Institute, Department of Respiratory and Sleep Medicine, John Hunter Hospital, Locked Bag \#1, Hunter Region Mail Centre, NSW 2310 Australia; mdpgg@ mail.newcastle.edu.au

Received 22 June 2003 Accepted 8 October 2003
Background: Written action plans for asthma facilitate the early detection and treatment of an asthma exacerbation. Several versions of action plans have been published but the key components have not been determined. A study was undertaken to determine the impact of individual components of written action plans on asthma health outcomes.

Methods: Randomised controlled trials $(n=26)$ that evaluated asthma action plans as part of asthma selfmanagement education were identified. Action plans were classified as being individualised and complete if they specified when and how to increase treatment $(n=17)$, and as incomplete $(n=4)$ or non-specific $(n=5)$ if they did not include these instructions.

Results: For individualised complete written action plans the use of 2-4 action points and the use of both inhaled (ICS) and oral (OCS) corticosteroid consistently improved asthma outcomes. Action points based on personal best peak expiratory flow (PEF) consistently improved health outcomes while those based on percentage predicted PEF did not. The efficacy of incomplete action plans was inconclusive because of insufficient data. Non-specific action plans led to improvements in knowledge and symptoms.

Conclusion: Individualised written action plans based on personal best PEF, using 2-4 action points, and recommending both ICS and OCS for treatment of exacerbations consistently improve asthma health outcomes. Other variations appear less beneficial or require further study. These observations provide a guide to the types of variations possible with written action plans, and strongly support the use of individualised complete written action plans.
E xacerbations of asthma usually occur gradually over several days to weeks or on a background of chronic poor asthma control. ${ }^{12}$ This provides an opportunity for early intervention with corticosteroids and $\beta$ agonists which act to reverse airflow obstruction and reduce the severity of the exacerbation. A written action plan facilitates the early detection and treatment of an exacerbation and is therefore an essential part of the self-management of exacerbations. ${ }^{3}$

Asthma is characterised by episodes of expiratory airflow obstruction which occur in response to multiple stimuli. The frequency and severity of these episodes varies greatly, both between and within individuals. Since all individuals with asthma are susceptible to exacerbations of asthma, it follows that all those with diagnosed asthma need to know how to manage these episodes. This instruction in self-management can be formalised as a written action plan, and all asthmatics are candidates for such a plan. This contrasts with the need for inhaled anti-inflammatory therapy which only becomes necessary when the frequency and/or severity of exacerbations are sufficiently great. At present, however, there is a paradoxical situation where most patients are prescribed regular inhaled corticosteroids (ICS) yet only a few either have ${ }^{45}$ or use ${ }^{6}$ a written action plan.

A recent systematic review of asthma self-management education conducted in adults ${ }^{3}$ identified 17 randomised controlled trials (RCTs) which evaluated written action plans compared with usual care. When a patient was provided with a written action plan and instructed in its use in the context of self-monitoring and a review of asthma medications and severity, there were highly significant improvements in asthma health outcomes. The risk of being admitted to hospital for asthma fell by over $40 \%$ and presentations to the emergency department with asthma fell by over $20 \%$ (relative risk (RR) $0.78,95 \%$ CI 0.67 to 0.91 ). Since action plans are highly effective when part of a planned self-management programme and many versions are available, it is reasonable to try to determine the key components of asthma action plans that make a difference to subjects with asthma. This study addresses this question.

\section{METHODS \\ Definitions}

Written action plan

An action plan is a set of instructions prescribed to a patient with asthma for use in the management of deteriorating asthma. An individualised written action plan is tailored to the patient's underlying asthma severity and treatment. It is further characterised by being a written plan which informs the subject about when and how to modify medications and how to access the medical system in response to worsening asthma. For the purpose of this review, written action plans were further classified as follows:

- Individualised complete written action plans contained each of the following four components of an action plan:

- when to increase treatment (action point);

- how to increase treatment;

- for how long;

- when to seek medical help.

- Incomplete individualised action plans comprised a second form of asthma self-management. These plans were individualised and specified when to increase treatment, but the use of early intervention with ICS was not specified.

- Non-specific action plans provided general information about the management of deteriorating asthma. 


\section{Action point}

Action plans prescribe a level of symptoms or lung function that determines when to activate the action plan. This is termed an action point. There are several variations in action points. Action points may be based on symptoms or peak expiratory flow (PEF). PEF based action points may be based on predicted or personal best PEF. The number of action points in any written action plan can also vary, generally between two and four different levels.

\section{Literature search}

To determine the impact of the individual components of written action plans on asthma health outcomes, RCTs that evaluated asthma action plans were identified. An initial broad search was conducted for RCTs on asthma education as part of a wider systematic review of asthma self-management education. ${ }^{3}$ Studies were identified from the Cochrane Airways Group Clinical Trials Register which is derived from Medline, Embase, Cinahl, hand searched respiratory journals, and meeting abstracts. Bibliographies of included studies were also searched. These articles were examined to identify those that included asthma action plans as part of the intervention. The asthma action plans were classified using the criteria described above.

\section{Analysis of data}

Data were extracted independently by two reviewers. The relative risk (RR) with 95\% confidence intervals (CI) was calculated for dichotomous outcomes. The RR is the probability of experiencing an outcome when treated compared with the probability of experiencing that outcome if untreated, with values of $<1$ indicating a favourable treatment effect. For continuous outcomes using different units of measure, a standardised mean difference (SMD) and 95\% CI was calculated using a fixed effects model. Significance was accepted at $\mathrm{p}<0.05$. The pooled results were tested for heterogeneity using a $\chi^{2}$ test with appropriate degrees of freedom. All outcomes were analysed according to the variations of the action plan and compared with a usual care control group. The variations analysed were: number of action points, personal best or percentage predicted PEF, "traffic light" action plan, or use of ICS or oral corticosteroids (OCS) alone.

\section{RESULTS}

Twenty six RCTs comparing action plans with usual care were identified (table 1), 17 of which used individualised complete written action plans. ${ }^{8-28}$ In 15 trials education, self-monitoring and regular medical review as well as provision of written action plans were incorporated into the self-management programmes. ${ }^{8-23} 25-28$ Four trials ${ }^{29-32}$ used incomplete individualised action plans and five used non-specific action plans. ${ }^{33-37}$

\section{Individualised complete written action plans Action points}

Full details of the individual action points for the written action plans are shown in table 2. The number and level of action points for when to increase treatment varied, but each trial gave some instruction on increasing treatment. Fifteen trials set their first action points at $70-85 \%$ of the personal best or predicted PEF value. ${ }^{8-15}{ }^{17-27}$ Action plans that used a personal best PEF were used in nine trials and six used percentage predicted PEF (table S1, figs S1-S4 available online only at www.thoraxjnl.com/supplemental). When compared with usual care in a meta-analysis (five and four trials respectively), both types of action plan reduced hospital admissions (RR 0.66 for personal best and 0.46 for percentage predicted; fig 1), whereas only the action plan based on personal best PEF reduced emergency room visits (RR 0.78; fig S2). Similarly, only the personal best written action plan led to improvement in airway calibre (SMD: PEF 0.56; fig 2).

The number of action points provided in the individualised plans ranged from two to four. Eight studies used written action plans with four action points ( six that could be used in a meta-analysis), whereas seven studies used written action plans with less than four action points (three that could be used in a meta-analysis). The use of two or three action points was consistently beneficial (figs 1 and 2; also table S2 and figs S5-S7 available online only at www.thoraxjnl.com/ supplemental), as was the use of four action points.

Action points were presented as a "traffic light" system ${ }^{38}$ in four trials. ${ }^{8}{ }^{10-14} 1822$ This was not consistently better than a conventional action plan presentation (fig 3; also table S3 and figs S8-S10 available online only at www.thoraxjnl.com/ supplemental).

The action plans were based on PEF in 10 trials $^{10-17} 19-$ 21252628 and on either PEF or symptoms in six trials. ${ }^{81022-2427}$ A previous systematic review found symptom based action plans to be equivalent to PEF based action plans. ${ }^{39}$

\section{Treatment instruction}

The instructions on how to increase corticosteroid treatment included the use of ICS and OCS in 13 trials and the use of OCS alone in four trials. ICS doses were increased by doubling the dose in 11 trials $^{9-15} 1^{18-24} 27$ and by increasing or commencing ICS in two trials. ${ }^{82}$ The use of both ICS and OCS in the individualised plans was consistently beneficial (figs 1 and 2; also table S4 and figs S11-S14 available online only at www.thoraxjnl.com/supplemental). No comparison could be made with the use of OCS alone (four studies) because of insufficient data. No studies used action plans based on ICS alone.

\section{Incomplete/non-specific plans}

The efficacy of incomplete action plans was inconclusive as there were too few studies reporting data that could be used in a meta-analysis. Non-specific action plans led to an improvement in knowledge, ${ }^{33} 36{ }^{37}$ symptoms, ${ }^{35}{ }^{36}$ and reduced healthcare use in some ${ }^{35}$ but not other studies. ${ }^{29}$ Incomplete data reporting precluded meta-analysis.

\section{DISCUSSION}

This study has identified the key components of asthma action plans and examined the variations possible in preparing these plans. By using meta-analyses of data from RCTs, we have compared the different variations for their effect on key asthma outcomes such as hospital admissions, emergency room visits, and lung function. The results (table 3) give clear recommendations for preparing action plans and highlight areas needing further research.

\section{Predicted or personal best PEF action points}

Individualised action plans can be based upon the predicted PEF or the personal best PEF for that individual. Action points based on personal best PEF consistently improved health outcomes, whereas those based on percentage predicted PEF did not. With personal best PEF as the basis of the action plan, there were reductions in hospital admissions, emergency room visits, and improvement in PEF. This suggests that action points based on personal best PEF may perform better than those based on percentage predicted PEF. The likely reasons for this difference relate to individual variability in PEF results. However, significant differences between percentage predicted and personal best PEF could not be determined because of an overlap of the confidence intervals. 


\begin{tabular}{|c|c|c|c|c|c|}
\hline \multirow[b]{2}{*}{ Study } & \multirow[b]{2}{*}{ Individualised } & \multicolumn{4}{|c|}{ Treatment instructions } \\
\hline & & $\begin{array}{l}\text { When to } \\
\text { increase } \\
\text { treatment }\end{array}$ & $\begin{array}{l}\text { How to } \\
\text { increase } \\
\text { treatment }\end{array}$ & $\begin{array}{l}\text { How long to } \\
\text { increase } \\
\text { treatment }\end{array}$ & $\begin{array}{l}\text { When to } \\
\text { get help }\end{array}$ \\
\hline \multicolumn{6}{|c|}{ Individualised written action plans } \\
\hline Cote et $a^{\beta}$ & Yes & Yes & Yes & Yes & Yes \\
\hline Cowie et $a^{p *} \dagger$ & Yes & Yes & Yes & Yes & Yes \\
\hline Gallefoss et al ${ }^{0-14}$ & Yes & Yes & Yes & Yes & Yes \\
\hline Ghosh ef $a l^{15 *}$ & Yes & Yes & Yes & Yes & Yes \\
\hline Grampian $^{16}$ & Yes & Yes & Yes & NS & Yes \\
\hline Hayward ef al ${ }^{77}$ & Yes & Yes & NS & NS & Yes \\
\hline Heard et $a l^{18} \dagger$ & Yes & Yes & Yes & Yes & Yes \\
\hline Ignacio-Garcia ${ }^{19}$ & Yes & Yes & Yes & Yes & Yes \\
\hline Jones et a $P^{0 * *}$ & Yes & Yes & Yes & Yes & Yes \\
\hline Lahdensuo et $a^{p 1}$ & Yes & Yes & Yes & Yes & Yes \\
\hline Levy et $a^{2 *}$ & Yes & Yes & Yes & Yes & Yes \\
\hline Moudgil et $a f^{3} \ddagger$ & Yes & Yes & Yes & Yes & Yes \\
\hline Perneger et $a P^{p^{4}}$ & Yes & Yes & Yes & NS & Yes \\
\hline Schermer et a $p^{5}$ & Yes & Yes & Yes & Yes & Yes \\
\hline Sommaragua et $a^{p b}$ & Yes & Yes & Yes & NS & Yes \\
\hline Yoon et $a^{77} \S$ & Yes & Yes & Yes & Yes & Yes \\
\hline Zeiger et $a^{P^{B}}$ & Yes & Yes & Yes & NS & NS \\
\hline \multicolumn{6}{|l|}{ Incomplete action plans } \\
\hline Bailey et a $p^{9}$ & Yes & NS & NS & NS & NS \\
\hline George et $a^{\beta 0}$ & $?$ & NS & NS & NS & NS \\
\hline Knoell et al $\boldsymbol{\beta}^{\beta 1}$ & Yes & NS & NS & NS & NS \\
\hline Kotses et $a^{\beta 2}$ & Yes & NS & NS & NS & NS \\
\hline \multicolumn{6}{|c|}{ Non-specific action plans } \\
\hline Abdulwadud et a ${ }^{\beta 3}$ & No & NS & NS & NS & NS \\
\hline Bailey et $a^{\beta 4}$ & No & NS & NS & NS & Yes \\
\hline Kotses et $a^{\beta 5}$ & No & NS & NS & NS & NS \\
\hline Mulloy et a ${ }^{\beta 6}$ & No & NS & NS & NS & NS \\
\hline Snyder et $a^{\beta^{7}}$ & No & NS & NS & NS & NS \\
\hline \multicolumn{6}{|c|}{$\begin{array}{l}\text { NS }=\text { not stated. } \\
{ }^{*} \text { Written action plan based on Beasley et al. }{ }^{47} \\
\text { +Written action plan based on Charlton. }{ }^{48} \\
\text { †Treatment based on British Thoracic Society guidelines. }{ }^{49} \\
\text { §Based on Woolcock. }{ }^{50}\end{array}$} \\
\hline
\end{tabular}

Initial versions of written action plans recommended that the same level of PEF should be applied to all patients in order to indicate when to increase treatment. This was expressed as either percentage predicted or percentage personal best PEF. This commonly was set at $80 \%$ or $60 \%$ of the predicted peak flow value. Such a level would be

Table 2 Details of individual written action plans

\begin{tabular}{|c|c|c|c|c|c|c|}
\hline \multirow[b]{2}{*}{ Study } & \multicolumn{4}{|c|}{ When to increase treatment } & \multicolumn{2}{|c|}{ How to increase treatment } \\
\hline & $\%$ Level & Traffic light & $\begin{array}{l}\text { No of action } \\
\text { point levels }\end{array}$ & PEF or symptom based & ICS & OCS \\
\hline 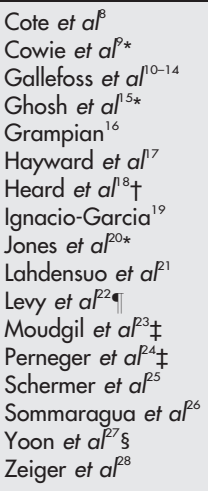 & 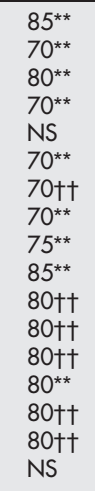 & $\begin{array}{l}\text { Yes } \\
\text { No } \\
\text { Yes } \\
\text { No } \\
\text { NS } \\
\text { NS } \\
\text { Yes } \\
\text { No } \\
\text { No } \\
\text { No } \\
\text { Yes } \\
\text { No } \\
\text { NS } \\
\text { NS } \\
\text { No } \\
\text { No } \\
\text { NS }\end{array}$ & $\begin{array}{l}4 \\
4 \\
4 \\
4 \\
\text { NS } \\
2 \\
4 \\
3 \\
4 \\
2 \\
3 \\
4 \\
4 \\
3 \\
3 \\
3 \\
\text { NS }\end{array}$ & $\begin{array}{l}\text { PEF/symptom } \\
\text { PEF/symptom } \\
\text { PEF } \\
\text { PEF } \\
\text { PEF } \\
\text { PEF } \\
\text { NS† } \\
\text { PEF } \\
\text { PEF } \\
\text { PEF } \\
\text { PEF/symptom } \\
\text { PEF/symptom } \\
\text { PEF/symptom } \\
\text { PEF } \\
\text { PEF } \\
\text { PEF/symptom } \\
\text { PEF }\end{array}$ & $\begin{array}{l}\text { BDP } 2000 \mu \mathrm{g} \\
\text { Double } \\
\text { Double/triple } \\
\text { Double } \\
\text { NS } \\
\text { NS } \\
\text { Double } \\
\text { Double } \\
\text { Double } \\
\text { Double } \\
\text { Double } \\
\text { Double } \\
\text { Double } \\
\text { Double or commence } \\
\text { No } \\
\text { Double } \\
\text { NS }\end{array}$ & $\begin{array}{l}\text { Yes } \\
\text { Yes } \\
\text { Yes } \\
\text { Yes } \\
\text { Yes } \\
\text { Yes } \\
\text { Yes } \\
\text { Yes } \\
\text { Yes } \\
\text { Yes } \\
\text { Yes } \\
\text { Yes } \\
\text { Yes } \\
\text { Yes } \\
\text { Yes } \\
\text { Yes } \\
\text { Yes }\end{array}$ \\
\hline \multicolumn{7}{|c|}{$\begin{array}{l}\text { NS }=\text { not stated; PEF = peak expiratory flow; ICS = inhaled corticosteroids; OCS = oral corticosteroids. } \\
\text { "Based on Beasley et al. }{ }^{47} \\
\text { †Based on Charlton. }{ }^{48} \\
\text { †Based on BTS. } \\
\text { §Based on Woolcock. } \\
\text { "Based on Beasley "credit card plan". } \\
\text { **Personal best PEF. } \\
\text { ††Predicted PEF. }\end{array}$} \\
\hline
\end{tabular}




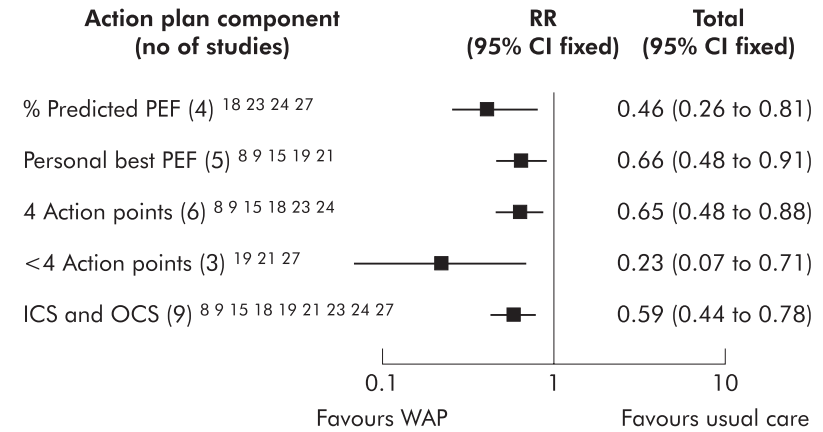

Figure 1 Comparison of the effects of action plan components on hospital admissions for asthma. WAP $=$ written action plan; $P E F=$ peak expiratory flow; ICS $=$ inhaled corticosteroids; $O C S=$ oral corticosteroids.

inappropriate for someone with moderate asthma who could have daily variability of peak flow of up to $30 \%$, and therefore their peak flow would regularly drop to $70 \%$ of the best during a stable period. Similarly, if there was any component of fixed airflow obstruction, the best peak flow may not reach $80 \%$ of the predicted value and the patient would be below their action point even when stable.

\section{Number of action points}

Action plans can use a variable number of action points. The studies in this review used two, three or four action points. Action plans with four action points were not consistently better than action plans with two or three action points (table S2 available online at www.thoraxjnl. com/supplemental). Using a greater number of action points leads to a narrower range of peak flow in each of the zones which may not be feasible to use in practice. These results argue in favour of a simpler approach using two or three action points. It may be that the improved precision obtained by using four action points is offset by the greater complexity of these plans which limits patient understanding and acceptance.

\section{Symptoms versus peak flow based action plan}

Written self-management plans can use action points that are based on either symptoms, peak flow, or both. Several RCTs have compared these approaches and found them to be equivalent for both the number of people admitted to hospital for asthma (RR 1.17, 95\% CI 0.44 to 3.12) and those attending the emergency department (RR 0.91, 95\% CI 0.61 to 1.35$).{ }^{39}$

\section{Presentation of written action plan}

A number of different ways of presenting action plans have been developed to facilitate their use. These include placing written self-management guidelines on a plastic card the size of a credit card, ${ }^{40}$ using electronic diaries or computerised "expert" systems, or the "traffic light" system where the colours green, yellow and red are used to signal continue usual treatment (green), increase treatment (yellow), or to seek help urgently (red). ${ }^{38}$ RCTs were identified that examined the "traffic light" approach. Individual written action plans without a "traffic light" action plan showed consistent benefits. There were fewer studies using a "traffic light" action plan configuration. Some outcomes were beneficial whereas others were not. This probably represents a lack of power rather than a lack of efficacy (table S3 available online at www.thoraxjnl.com/ supplemental).

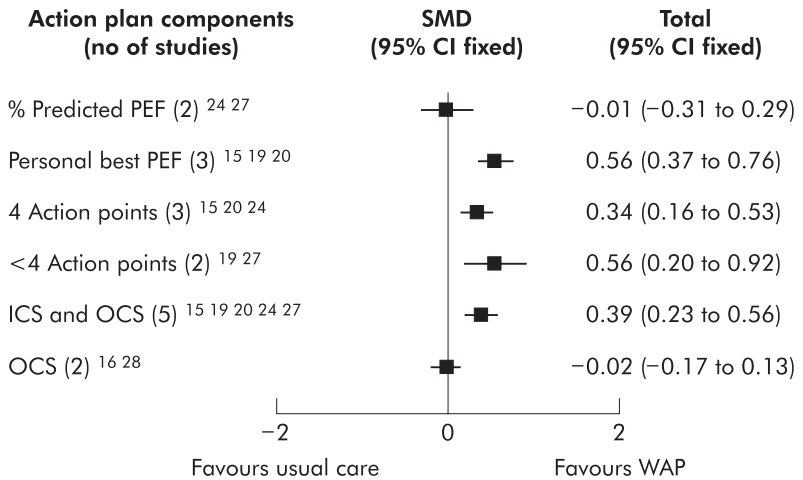

Figure 2 Comparison of the effects of action plan components on mean peak expiratory flow (PEF) in asthma. WAP = written action plan; ICS = inhaled corticosteroids; OCS = oral corticosteroids;

$\mathrm{SMD}=$ standardised mean difference.

Treatment instruction: how to increase treatment

An exacerbation of asthma consists of a deterioration in both airflow obstruction and airway inflammation. ${ }^{41}{ }^{42}$ It is therefore appropriate to recommend treatment with both bronchodilators and corticosteroids. A meta-analysis has confirmed the strong beneficial effect of OCS in severe exacerbations of asthma. ${ }^{43}$ The optimal treatment of mild exacerbations of asthma (forced expiratory volume in l second $>60 \%$ predicted) is less clear. Current management practices include increased $\beta_{2}$ agonists, ICS, and OCS. A recent randomised trial conducted in a primary care setting compared fluticasone $1 \mathrm{mg}$ twice daily with prednisone (40 mg daily and reducing). Treatment of a mild exacerbation with ICS had a comparable success rate to the use of ingested prednisone ( $48 \% \vee 48 \%)$. There was a surprisingly high rate of treatment failure in both groups $(27 \%$ and $23 \%$, respectively). ${ }^{44}$ This failure rate may reflect inadequate doses, inadequate duration of treatment, or non-eosinophilic exacerbations. ${ }^{45}$ Doubling ICS was found to be less effective than OCS in another trial. ${ }^{46}$ The studies in this review support a combined approach where both ICS and OCS are used in the action plan.

\section{Limitations}

This review has used data derived from RCTs of asthma selfmanagement programmes where written action plans were a key component. There are a number of limitations that need to be considered when reviewing these data. In some cases there were insufficient studies to allow a comparison and hence a type II error is possible. Where this is the case-for example, in the comparison of OCS with ICS and OCS-we

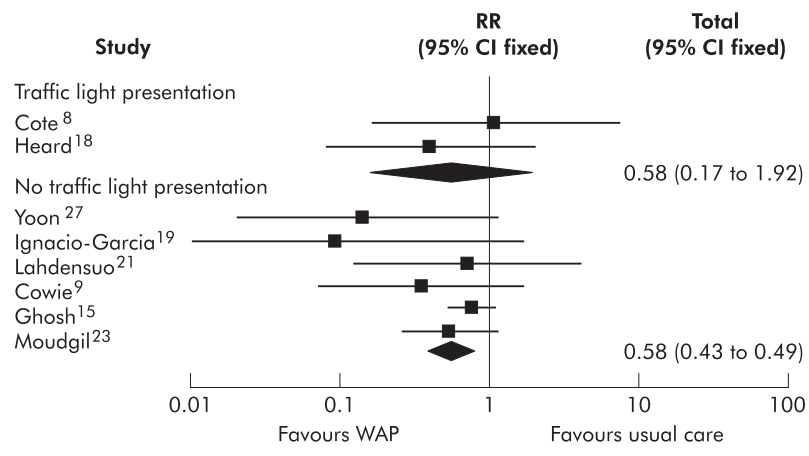

Figure 3 Comparison of the effects of different action plan presentations (traffic light versus other) on hospital admissions for asthma. WAP = written action plan. 
Table 3 Action plan variations: summary of results

\begin{tabular}{|c|c|}
\hline Action plan variation & Result \\
\hline \multicolumn{2}{|l|}{ Action points } \\
\hline Symptoms $v$ PEF triggered & Equivalent \\
\hline Standard written instruction & Consistently beneficial \\
\hline Traffic light configuration & $\begin{array}{l}\text { Not clearly better than } \\
\text { standard instruction }\end{array}$ \\
\hline 2-3 action points & Consistently beneficial \\
\hline 4 action points & $\begin{array}{l}\text { Not clearly better than } \\
<4 \text { points }\end{array}$ \\
\hline PEF based on & Consistently beneficial \\
\hline $\begin{array}{l}\text { personal best PEF } \\
\text { PEF based on \% } \\
\text { predicted PEF }\end{array}$ & $\begin{array}{l}\text { Not consistently better } \\
\text { than usual care }\end{array}$ \\
\hline \multicolumn{2}{|l|}{ Treatment instruction } \\
\hline $\begin{array}{l}\text { Individualised WAP } \\
\text { using ICS and OCS }\end{array}$ & Consistently beneficial \\
\hline Individualised WAP & Insufficient data to evaluate \\
\hline $\begin{array}{l}\text { Individualised WAP } \\
\text { using ICS only }\end{array}$ & Insufficient data to evaluate \\
\hline $\begin{array}{l}\text { WAP = written action plan; } \\
I C S=\text { inhaled corticosteroid; }\end{array}$ & $\begin{array}{l}\mathrm{PEF}=\text { peak expiratory flow; } \\
\mathrm{OCS}=\text { oral corticosteroid }\end{array}$ \\
\hline
\end{tabular}

have been cautious in our interpretation of the data, reported the number of studies contributing to the meta-analysis, and only reported on outcomes where several studies contributed data. There are likely to be differences in the way the different self-management programmes were implemented. This does not seem to have a major impact on the results since there was no statistical heterogeneity identified in the key results.

\section{Conclusion}

The provision of individualised written action plans is of benefit to patients with asthma. Effective plans can be based on symptoms or PEF and use two, three or four action points. PEF based plans should use personal best PEF for the action point. The treatment instruction should include both ICS and OCS. With the data available, there was no clear distinction between other variations in the components of asthma action plans such as whether they were based on a traffic light system, the number of action points, or use of ICS alone or OCS alone. For these variations to be fully evaluated they need to be compared directly with each other, not a control group, in a randomised controlled trial setting of individualised written action plans. The observations of this review provide a guide to the types of variations possible with written action plans and strongly support the use of individualised complete written action plans.

\section{ACKNOWLEDGMENTS}

The authors acknowledge the Cooperative Research Centre for Asthma, Hunter Area Health Service - Chronic Disease Management Project.

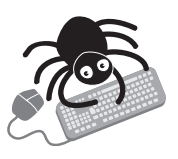

Figures S1-S14 and tables S1-S4 are available on the Thorax website at www.thoraxinl.com/supplemental.

\section{Authors' affiliations}

P G Gibson, H Powell, Hunter Medical Research Institute, Department of Respiratory and Sleep Medicine, John Hunter Hospital, Newcastle, NSW, Australia

\section{REFERENCES}

1 Chan-Yeung M, Chang JH, Manfreda J, et al. Changes in peak flow, symptom score and the use of medications during acute exacerbations of asthma. Am J Respir Crit Care Med 1996;154:889-93.

2 Turner MO, Noertiojo K, Vedal S, et al. Risk factors for near fatal asthma. Am J Respir Crit Care Med 1998;157:1804-9.

3 Gibson PG, Powell H, Coughlin J, et al. Self-management education and regular practitioner review for adults with asthma (Cochrane review). In: The Cochrane Library, Issue 1. Oxford: Update Software, 2003.

4 Matheson M, Wicking J, Raven J, et al. Asthma management: how effective is it in the community? Intern Med J 2002;32:451-6.

5 Hartet TV, Windoss HH, Peebles RS Jr, et al. Inadequate out-patient medical therapy for patients with asthma admitted to two urban hospitals. Am J Med 1996; 100:386-94.

6 Marks GB, Burney PG, Premaratne UN, et al. Asthma in Greenwich UK: impact of the disease and current management practices. Eur Respir $J$ 1997; 10:1224-9.

7 Hargreave FE, Dolovich J, Newhouse MT. The assessment and treatment of asthma: a conference report. J Allergy Clin Immunol 1990;85:1098-111.

8 Cote J, Cartier A, Robichaud P, et al. Influence on asthma morbidity of asthma education programs based on self-management plans following treatment optimisation. Am J Respir Crit Care Med 1997;155:1509-14.

9 Cowie RL, Revitt SG, Underwood MF, et al. The effect of a peak flow-based action plan in the prevention of exacerbations of asthma. Chest 1997; 112:1134-8.

10 Gallefoss F, Bakke PS, Kjaersgaard P. Quality of life assessment after patient education in a randomized controlled study on asthma and chronic obstructive pulmonary disease. Am J Respir Crit Care Med 1999;159:812-7.

11 Gallefoss F, Bakke PS. How does patient education and self-management among asthmatics and patients with chronic obstructive pulmonary disease affect medication? Am J Respir Crit Care Med 1999;160:2000-5.

12 Gallefoss F, Bakke PS. Impact of patient education and self-management on morbidity in asthmatics and patients with chronic obstructive pulmonary disease. Respir Med 2000;94:279-87.

13 Gallefoss F, Bakke PS. Cost-effectiveness of self-management in asthmatics: a 1 year follow-up randomized, controlled trial. Eur Respir $J$ $2001 ; 17: 206-13$.

14 Gallefoss F, Bakke PS. Patient satisfaction with health care in asthmatics and patients with COPD before and after patient education. Respir Med 2000;94:1057-64.

15 Ghosh CS, Ravindran P, Joshi M, et al. Reductions in hospital use from self management training for chronic asthmatics. Soc Sci Med 1998;46:1087-93.

16 Grampian Asthma Study of Integrated Care (GRASSIC). Effectiveness of routine self monitoring of peak flow in patients with asthma. BMJ 1994;308:564-7.

17 Hayward SA, Jordan M, Golden G, et al. A randomised controlled evaluation of asthma self management in general practice. Asthma Gen Pract 1996;4:11-13.

18 Heard AR, Richards IJ, Alpers JH, et al. Randomised controlled trial of general practice based asthma clinics. Med J Aust 1999;171:68-71.

19 Ignacio-Garcia JM, Gonzalez-Santos P. Asthma self-management education program by home monitoring of peak expiratory flow. Am J Respir Crit Care Med 1995;151:353-9.

20 Jones KP, Mullee MA, Middleton M, and the British Society Research Committee, et al. Peak flow based asthma self management: a randomised controlled study in general practice. Thorax 1995;50:851-7.

21 Lahdensuo A, Haahtela T, Herrala J, et al. Randomised comparison of guided self-management. BMJ 1996;312:748-52.

22 Levy ML, Robb M, Allen J, et al. A randomized controlled evaluation of specialist nurse education following accident and emergency attendance for acute asthma. Respir Med 2000;94:900-8.

23 Moudgil H, Marshall T, Honeybourne D. Asthma education and quality of life in the community: a randomised controlled study to evaluate the impact on white European and Indian subcontinent ethnic groups from socioeconomically deprived areas in Birmingham, UK. Thorax 2000;55: 177-83.

24 Perneger TV, Sudre $\mathrm{P}$, Muntner $\mathrm{P}$, et al. Effect of patient education on selfmanagement skills and health status in patients with asthma: a randomized trial. Am J Med 2002;11:7-14.

25 Schermer TR, Thoonen BP, van den Boom G, et al. Randomized controlled economic evaluation of asthma self-management in primary health care. Am J Respir Crit Care Med 2002;166:1062-72.

26 Sommaruga M, Spanevello A, Migliori GB, et al. The effects of a cognitive behavioural intervention in asthmatic patients. Monaldi Arch Chest Dis 1995;50:398-402.

27 Yoon R, McKenzie DK, Bauman A, et al. Controlled trial evaluation of an asthma education program for adults. Thorax 1993;48:1110-6.

28 Zeiger RS, Heller S, Mellon MH, et al. Facilitated referral to asthma specialist reduces relapses in asthma emergency room visits. J Allergy Clin Immunol 1991:87:1160-8.

29 Bailey WC, Kohler CL, Richards JM, et al. Asthma self-management: do patient education programs always have an impact? Arch Intern Med 1999;159:2422-8.

30 George MR, O'Dowd LC, Martin I, et al. A comprehensive educational progamme improves clinical outcome measures in inner-city patients with asthma. Arch Intern Med 1999;159:1710-6.

31 Knoell DL, Pierson JF, Marsh CB, et al. Measurement of outcomes in adults receiving pharmaceutical care in a comprehensive asthma outpatient clinic. Pharmacotherapy 1998;18:1365-74. 
32 Kotses $\mathrm{H}$ Stout $\mathrm{C}, \mathrm{Mc}$ Connaughty $\mathrm{K}$, et al. Evaluation of individualized asthma self-management programs. J Asthma 1996;33:113-8.

33 Abdulwadud O, Abramson M, Forbes A, et al. Evaluation of a randomised controlled trial of adult asthma education in a hospital setting. Thorax 1999;54:493-500.

34 Bailey WC, Richards JM, Brooks CM, et al. A randomised trial to improve selfmanagement practices of adults with asthma. Arch Intern Med 1990;150:1664-8.

35 Kotses H, Bernstein IL, Bernstein DL, et al. A self-management program for adult asthma. Part 1: Development and evaluation. J Allergy Clin Immunol 1995;95:529-40

36 Mulloy E, Donaghy D, Quigley C, et al. A one-year prospective audit of an asthma education programme in an out-patient setting. Ir Med J 1996;89:226-8.

37 Snyder SE, Winder JA, Creer TL. Development and evaluation of an adult asthma self-management program: wheezers anonymous. J Asthma 1987; $24: 153-8$

38 Lewis CE, Rachelefsky G, Lewis MA, et al. A randomised trial of asthma care training for kids. Pediatrics 1984:74:478-86.

39 Powell H, Gibson PG. Options for self-management education for adults with asthma (Cochrane review). In: The Cochrane Library, Issue 1. Oxford: Update Software, 2003.

40 D'Souza W, Crane J, Burgess C, et al. Community-based asthma care: trial of a "credit card" asthma self-management plan. Eur Respir J 1994;7:1260-5.
41 Gibson PG, Wong BJO, Hepperle MJG, et al. A research method to induce and examine a mild exacerbation of asthma. Clin Exp Allergy 1992;22:525-32.

42 Pizzichini MM, Pizzichini E, Efthimiadis A, et al. Asthma and natural colds. Inflammatory indices in induced sputum: a feasibility study. Am J Respir Crit Care Med 1998; 158:1178-84.

43 Rowe BH, Keller JL, Oxman AD. Effectiveness of steroid therapy in acute exacerbations of asthma: a meta-analysis. Am J Emerg Med 1992;10:301-10.

44 Gibson PG. Corticosteroids - clinical applications: exacerbations of asthma in adults. Aust Prescr 1996;19:44-6.

45 Turner MO, Hussack P, Sears MR, et al. Exacerbations of asthma without sputum eosinophilia. Thorax 1995;50:1057-61.

46 Fitzgerald JM, Shragge D, Haddon J, et al. A randomized, controlled trial of high dose, inhaled budesonide versus oral prednisone in patients discharged from the emergency department following an acute asthma exacerbation. Can Respir J 2000;7:61-7.

47 Beasley R, Cushley M, Holgate ST. A self management plan in the treatment of adult asthma. Thorax 1989:44:200-4.

48 Charlton I, Antoniou AG, Atkinson J, et al. Asthma at the interface: bridging the gap between general practice and a district hospital. Arch Dis Child 1994; 70:313-8

49 British Thoracic Society. The British guidelines on asthma management: 1995 review and position statement. Thorax 1997:52(Suppl 1):S1-20.

50 Woolcock A, Rubinfeld AR, Searle P, et al. Asthma management plan. Med J Aust 1989;151:650-3.

\section{LUNG ALERT}

\section{No clear benefit of parent initiated oral steroids in preschool children with viral wheeze}

A Oommen A, Lambert PC, Grigg J. Efficacy of a short course of parent-initiated oral prednisolone for viral wheeze in children aged 1-5 years: randomised controlled trial. Lancet 2003;362:1433-8

A sthma in children aged 1-5 years is characterised by recurrent transient episodes of wheeze triggered by viral colds. This is labelled "preschool viral wheeze" and is commonly treated with inhaled bronchodilators and oral corticosteroids. Persistent wheeze is associated with increased systemic eosinophil priming which is thought to be a risk factor for the development of atopic asthma.

In this randomised placebo controlled trial, children aged 1-5 years with known viral wheeze were stratified into either high or low eosinophil priming groups and parents administered $20 \mathrm{mg}$ prednisolone or placebo for 5 days at the start of the next episode of viral wheeze. The primary outcomes were 7 day mean daytime and night time respiratory symptom scores.

217 children were randomised and outcome data were available for 51 and 69 children who received prednisolone or placebo, respectively. There was no improvement in daytime and night time symptom scores and no reduction in salbutamol use and hospital admissions in children treated with prednisolone compared with placebo. There were no differences between high or low eosinophil priming groups.

This study suggests no clear benefit of parent initiated oral prednisolone for preschool viral wheeze.

S S Birring

Specialist Registrar, Institute for Lung Health,

Department of Respiratory Medicine, Glenfield Hospital, Leicester, UK

sb134@le.ac.uk 